\title{
Okul Öncesi Eğitimde Ailelerin Kreş Tercihleri ve Kreşlerden Beklentileri: Eskişehir Örneği
}

\author{
Fatih ÇEMREK, Özer ÖZAYDIN*
}

Okul Öncesi Eğitimde Ailelerin Kreş Tercihleri ve Kreş-
lerden Beklentileri: Eskişehir Örneği

Özet

Bu çalışmada Eskişehir'de yaşayan ve çocukları kreşe giden ailelerinin kreş tercihi ve kreşlerden beklentileri tespit etmeye çalışılmıştır. Bu amaçla araştırmacılar tarafından bir anket formu hazırlanmıştır. Sözkonusu anket formu Eskişehir'de yaşayan ve 2015-2016 öğretim yılında kreşe giden çocukları olan aileler arasından rasgele seçilen 440 aileye 2015 Aralık-2016 Nisan ayı arasında uygulanmıştır. Araştırmada kullanılan ankette yer alan sorular iki bölümden oluşmuştur. Birinci bölümde ailelerin sosyo-ekonomik özelliklerine ilişkin sorular yer almaktadır. İkinci bölümde ise, ailelerin kreş tercihi ve kreşlerden beklentilerine ilişkin olarak beşli likert tipi 23 tutum sorusu yer almıştır. Bu 23 sorudan alınan cevaplarla faktör analizi yapılmış ve sorular beş faktörde yer almıştır.

Anahtar Kelimeler: Kreş, Kreş Tercihi, Eskişehir, Faktör Analizi

\section{Giriş}

Okul öncesi eğitim çocuğun doğduğu andan ilkokula başlayana kadar geçirdiği dönemde aldığı eğitimi kapsamaktadır. Bu nedenle, "Erken Çocukluk Eğitimi" olarak da adlandırılmaktadır (Kanbak Ay ve diğerleri, 2016).

Okul öncesi dönem çocuğun en hızlı geliştiği dönemdir. Konu ile ilgili yapılan bilimsel araştırmalar ile okul öncesi eğitim alan çocukların daha fazla oranda okula devam ettiği ve okulda daha başarılı olduğu ve okula daha iyi uyum sağladığı belirlenmiştir (Erkan ve Kır-

\footnotetext{
*Fatih ÇEMREK, Doç.Dr., Eskişehir Osmangazi Üniversitesi Fen-Edebiyat Fakültesi, fcemrek@ogu.edu.tr, ORCID ID: orcid.org/0000-0002-6528-7159, Özer ÖZAYDIN, Dr. Öğr. Üyesi Eskişehir Osmangazi Üniversitesi Fen-Edebiyat Fakültesi, oozaydin@ogu.edu.tr, ORCID ID: orcid.org/0000-0001-6657-1162
} 
Fatih ÇEMREK | Özer ÖZAYDIN

ca, 2010; Bozan, 2014; Yoleri ve Tanış, 2014). Okul öncesi eğitim çocuğun sosyal ve duygusal gelişimini desteklemesinin yanında bireylerin ileriki yaşantılarında da üretkenliklerini ve verimliliklerini arttırmaktadır.

Okul öncesi eğitim, yoksulluk ve eşitsizliğin nesilden nesle geçişinin engellenmesi ve kadınların daha fazla işgücüne katılmasını sağlamak için yapılabilecek etkili yatırımlardan birisi olarak görülmektedir (Şimşek ve İvrendi, 2014). Okul öncesi eğitim döneminde, çocuklar, bedensel, zihinsel, duygusal, psiko-motor, sosyal, zihinsel ve dil gibi birçok alandaki gelişmelerinin büyük bölümünü tamamlamaktadırlar (Aral vd. 2002; Aktaran: Mutlu vd. 2012).

Eğitimin en önemli amaçlarından biri, bireyin yaşadığı çevreye ve ortama uyumlu olarak yaşayabilmesini sağlamaktır. Bu uyumun sağlanması konusunda okul öncesi eğitime de önemli sorumluluklar düşmektedir (Kobak, 2009). Çocukların yeni ortamlara uyum sağlama becerisi oldukça iyidir. Ancak, bu uyum sağlama yeteneği anne-babalar tarafından engellenmemelidir. Anne-babalar çocuklarının kreşe başlama kararı konusunda ne kadar rahat olurlarsa, anne babaların ve çocukların karşılaştıkları sorunların azalacağı düşünülmektedir. Öte yandan çocukların okul öncesi eğitimden kazanımlarının yüksek olacağı inancı ebeveynlerin rahatlamasına da katkı sağlayabilir.

Oktay (2002) okul öncesi eğitimin evrensel amaçlarının toplumsal, eğitici ve gelişimsel amaçlar olmak üzere üç başlık altında toplandığını belirtmektedir. Bu kapsamda okul öncesi eğitimin temel amaçları bağlamında Türkiye'de de 36-72 ay arası çocukların eğitimi Milli Eğitim Bakanlığı tarafından hazırlanan Okul Öncesi Eğitim Programı uygulanmaktadır. Bu program "gelişimsel" bir programdır ve çocukların sosyal, psiko-motor, duygusal dil ve bilişsel alanlardaki gelişimlerinin desteklenmesini esas almaktadır.

Çocukların özelliklerini bilmeden verilen eğitim çocuğun bir birey olarak gelişimini ve tüm yaşamını olumsuz şekilde etkileyebilir. Bu nedenle toplum ve aileler okul öncesi eğitime oldukça önem vermektedir. Okul öncesi eğitim ile çocuklara öz bakım, dil, duygu, ilkokula hazırlık gibi konularda bilişsel ve duyuşsal yeterlilikler kazandırılması amaçlanmaktadır. Bu sayede çocukların ileriki yaşamlarında daha başarılı olacakları göz ardı edilemez bir gerçektir (Aslanargun ve Tapan,2012). Bu nedenle erken çocukluk adı verilen bu gelişim programları, çocuğa erken çevresel destek verilmesi ve çocuğun kendi gücünü geliştirmek bakımından önemlidir (Kargı, 2011).

Okul öncesi eğitimin amaç, işlev ve yararları göz önüne alındığında okul öncesi eğitimin tüm çağ nüfusuna ulaştırması gereklikten daha çok zorunluluktur. Nitekim başta MEB olmak üzere Türkiye'de okul öncesi eğitim kurumları yaygınlaştırarak ve okul öncesi eği- 
tim yaşı düşürülerek bu hizmet geniş kitlelere ulaştırılmaya çalışılmaktadır. Son yıllarda, özellikle şehir merkezlerinde kamu kurumlarına bağlı okul öncesi eğitim kurumlarının sayısının hızlı bir şekilde artış gösterdiği (Polat ve Çelmeli, 2015) görülmektedir. Başta kamu kurumları olmak üzere özel eğitim kurumlarının da katkısıyla okul öncesi eğitimde hem okullaşma oranlarının hem de okula erişim oranlarının gittikçe arttığını söylemek mümkündür. Okul öncesi eğitimde son on yıldaki sayısal veriler Tablo 1'de verilmiştir.

Tablo1. Türkiye'de 2008-2018 Dönemi Arasında Okul Öncesi Eğitimde Sayısal Gelişmeler

\begin{tabular}{cccc}
\hline \hline Öğretim Yılı & $\begin{array}{c}\text { Okul } \\
\text { Sayısı }\end{array}$ & $\begin{array}{c}\text { Öğrenci } \\
\text { Sayıs }\end{array}$ & $\begin{array}{c}\text { Öğretmen } \\
\text { Sayıs }\end{array}$ \\
\hline $2008-2009$ & 23.653 & 804.765 & 28.848 \\
$2009-2010$ & 26.681 & 980.654 & 26.498 \\
$2010-2011$ & 27.606 & 1.115 .818 & 32.516 \\
$2011-2012$ & 28.625 & 1.169 .556 & 55.883 \\
$2012-2013$ & 27.197 & 1.077 .933 & 62.933 \\
$2013-2014$ & 26.698 & 1.059 .495 & 63.327 \\
$2014-2015$ & 26.972 & 1.156 .661 & 68.038 \\
$2015-2016$ & 27.793 & 1.209 .106 & 72.228 \\
$2016-2017$ & 29.293 & 1.326 .123 & 77.109 \\
$2017-2018$ & 31.246 & 2501.088 & 57.257 \\
\hline
\end{tabular}

Kaynak: (Millî Eğitim İstatistikleri Örgün Eğitim 2017-2018)

Tablo 1'de görüldüğü gibi Türkiye'de 2008-2016 arası eğitim-öğretim yıllarında okul öncesi eğitim kurumlarında görev yapan öğretmen sayısı her yıl artmıştır. 2011-2012 eğitim öğretim yılından 2015-2016 eğitim öğretim yılına kadar okul öncesi eğitimde hizmet veren okul sayısında ise bir azalma meydana gelmiştir. 2012-2013 ve 2013-2014 yıllarında okul öncesi eğitim kurumlarına kayıt yaptıran öğrenci sayısında da bir azalma olduğu görülmektedir. 2017-2018 eğitim öğretim yılında hizmet veren okul sayısı 29.293 olurken, bu okullara kayıt yaptıran öğrenci sayısı 1.326 .123 ve çalışan öğretmen sayısı da 57.257 olmuştur.

Araştırmanın gerçekleştirildiği şehir olan Eskişehir'de de Türkiye genelindeki durumu yansıtan bir sayısal dağılımın olduğunu söylemek mümkündür. Buna göre Eskişehir'deki okul öncesi eğitimde ilişkin son on yıldaki sayısal veriler de Tablo 2'de sunulmuştur. 
Fatih ÇEMREK | Özer ÖZAYDIN

Tablo 2. Eskişehir'de 2008-2018 Arası Okul Öncesi Eğitimde Sayısal Gelişmeler (http://www.meb.gov.tr/)

\begin{tabular}{cccc}
\hline \hline Öğretim Yılı & $\begin{array}{c}\text { Okul } \\
\text { Sayıs }\end{array}$ & $\begin{array}{c}\text { Öğrenci } \\
\text { Sayıs }\end{array}$ & $\begin{array}{c}\text { Öğretmen } \\
\text { Sayısı }\end{array}$ \\
\hline $2008-2009$ & 202 & 7.232 & 323 \\
$2009-2010$ & 241 & 9.959 & 355 \\
$2010-2011$ & 227 & 9.951 & 418 \\
$2011-2012$ & 231 & 10.463 & 542 \\
$2012-2013$ & 205 & 9.785 & 617 \\
$2013-2014$ & 203 & 10.136 & 667 \\
$2014-2015$ & 204 & 11.300 & 741 \\
$2015-2016$ & 205 & 11.480 & 775 \\
$2016-2017$ & 87 & 18.028 & 495 \\
$2017-2018$ & 115 & 15.670 & 658 \\
\hline
\end{tabular}

Kaynak: (Millî Eğitim İstatistikleri Örgün Eğitim 2016-2017 ve 2017-2018)

Tablo 2'de de görüldüğü gibi Eskişehir'de 2010-2011 ve 2012-2013 öğretim yıllarında okul öncesi eğitim veren okul sayısında ve öğrenci sayısında Tablo 1'de verilen Türkiye'deki sayısal dağılımlarda olduğu bir azalma meydana gelmiştir. Öğretmen sayısı 20082016 eğitim-öğretim yılları arasında sürekli olarak artmaya devam etmiştir.

Okul öncesi eğitime ve ailelerin okul öncesi eğitimden beklentilerine yönelik kimi çaış̧maların yapıldığı görülmektedir. Buna göre yapılan çalışmalardan elde edilen sonuçlar incelendiğinde, okul öncesi eğitim yapılan sınıfta yer alan çocuk sayısı ve anne eğitim düzeyinin okul öncesi kurumunun kalitesi beklentisi etkilediği belirlenmiştir.

Ayrıca, anaokulu öğretmeninin dört yıllık eğitim veren okul öncesi lisans eğitimi almış olması, öğretmenlerin tecrübeli olması, okul öncesi eğitim yapılarında eğitim gören çocukların fiziksel özelliklerine uygun çevre koşulları oluşturulması beklenmektedir. Okul öncesi eğitim kurumlarının en önemli amacının çocukları ilkokula hazırlamak, çocukların öz-bakım becerilerini kazandırmak olduğunu ve çocuklara paylaşma, işbirliği gibi sosyal becerileri öğretmek olduğu da önem verilen konular arasındadır (Sevinç,2006; Tuğrul ve Tokuç,2007; Baran vd., 2007; Argon ve Akkaya,2008; Pianta ve arkadaşları, 2010; Topaç vd., 2012; , Kıldan, 2012; Rentzou, 2012; Şimşek ve İvrendi,2014; Özen Altınkaynak ve Yanıklar, 2014; Durualp vd., 2016; Polat Yaman ve Saçkes, 2017; Peterson et al ,2018) 
Bu çalışmada Eskişehir'de 0-6 yaş grubunda çocuğa sahip olan ailelerin kreş tercihleri ve kreşlerden beklentileri belirlenmeye çalışılmıştır. Ayrıca ailelerin demografik özelliklerinin, kreşlerden beklentileri üzerindeki etkisi de bu araştırmada ele alınan önemli unsurlardan biri olarak görülmektedir.

\section{Yöntem}

\subsection{Araştırma Deseni}

Eskişehir'de yaşayan ve çocukları kreşe giden ailelerinin kreş tercihi ve kreşlerden beklentilerini belirlemeyi amaçlayan bu araştırma temel nicel analiz yaklaşımına göre desenlenmiştir.

\subsection{Evren ve Örneklem}

Çalışmanın araştırma evrenini 2015-2016 öğretim yılında Eskişehir'de kreşe giden çocukların ailelerinin tamamı oluşturmaktadır. Örneklemde yer alacak birim sayısı belirlenirken önceden belirlenen sabit bir örnekleme oranı kullanılabilir. Bir başka yol ise hazır tablolardan yararlanılabilir. Söz konusu tabloda örnekleme hatasının yüzde beş ve evrendeki birim sayısı bir milyon olduğunda, örneklemde yer alacak birim sayısının 384 olduğu ifade edilmektedir (Arıkan, 2004:152; Yazıcıoğlu ve Erdoğan, 2004:50). Bu araştırmada da örneklem tayininde söz konusu tablo verilerinden yararlanılmıştır. Bu kapsamda araştırmanın örneklemini 2015-2016 öğretim yılında Eskişehir'de kreşe giden çocukların aileleri arasından rassal olarak seçilen 440 ailenin tamamı oluşturmuştur.

\subsection{Verilerin Toplanması}

Eskişehir'de yaşayan ve çocukları kreşe giden ailelerinin kreş tercihi ve kreşlerden beklentilerini belirlemeyi amaçlayan bu araştırmada araştırmacılar tarafından geliştirilen ve 23 sorudan oluşan bir ölçek kullanılmıştır. Araştırmada kullanılan anket formunda yer alan sorular iki bölümden oluşmuştur. Birinci bölümde ailelerin sosyo-ekonomik özelliklerine ilişkin sorular yer almaktadır. İkinci bölümde ise, ailelerin kreş tercihi ve kreşlerden beklentilerine ilişkin olarak tutum ve görüşlerin yer aldığı 23 madde yer almıştır. Bu soruların cevaplandırılmasında 5'li likert tipi kullanılmıştır. Her bir soru için cevaplayıcılar, 1:Kesinlikle Katılmıyorum, 2: Katılmıyorum, 3:Kararsızım, 4:Katılıyorum ve 5: Kesinlikle Katılıyorum şeklindeki seçeneklerden en uygun seçeneği işaretlemişlerdir. Araştırma, 2015 yılının Aralık ayında başlanmış olup 2016 yılının Nisan ayında tamamlanmıştır. Toplamda 440 aileye ulaşılmış ve 440 kişiye hazırlanan ölçek uygulanmıştır. Hazırlanan ölçekte yer alan maddelerin hangi faktör altında toplandığı ve bu maddelerin faktör yüklerini belirlemek için faktör analizi uygulanmıştır. 


\section{Bulgular ve Yorum}

Ankete verilen cevapların iç tutarlılığını belirlemek için Cronbach $\alpha$ güvenilirlik katsayısı kullanılmıştır. Ailelerin kreş tercihinde ve kreşlerden beklentileri belirlemek üzere ailelerin tutumlarının yer aldığı 23 soru için güvenilirlik analizi uygulanmıştır. Güvenirlik analizi sonucunda Cronbach $\alpha$ değeri 0.854 olarak hesaplanmıştır. Ayrıca, değişkenler arasında ters yönlü korelasyona sahip değişkene rastlanmamıştır. Hesaplanan Cronbach $\alpha$ değeri e 0.80 'den büyük olduğundan kullanılan anketin güvenirliği oldukça yüksek olduğu belirlenmiştir.

\subsection{Demografik Özelliklerin Frekans Tablosu}

Araştırmaya katılan 440 kişinin sosyal ve demografik özelliklerine ilişkin elde edilen sonuçlar Tablo 3'te verilmiştir.

Tablo 3. Araştırmaya Katılanların Sosyal ve Demografik Özellikleri

\begin{tabular}{|c|c|c|c|}
\hline Değişken & Düzey & Frekans & Yüzde \\
\hline \multirow[t]{2}{*}{ Cinsiyet } & Kadin & 293 & 66,6 \\
\hline & Erkek & 147 & 33,4 \\
\hline \multirow{4}{*}{ Yaş } & $25-34$ & 110 & 25,0 \\
\hline & $35-44$ & 249 & 56,6 \\
\hline & $45-54$ & 55 & 12,5 \\
\hline & 55 veüzeri & 26 & 6.0 \\
\hline \multirow{5}{*}{ Gelir } & 1000 TL'den az & 25 & 5,7 \\
\hline & $1000-2000 \mathrm{TL}$ & 91 & 20,7 \\
\hline & $2000-3000 \mathrm{TL}$ & 157 & 35,7 \\
\hline & $3000-4000 \mathrm{TL}$ & 129 & 29,3 \\
\hline & 4000 TL'den fazla & 38 & 8,6 \\
\hline \multirow{3}{*}{ Eğitim } & Ortaokul & 21 & 4,8 \\
\hline & Lise & 114 & 25,9 \\
\hline & Üniversite & 305 & 69,3 \\
\hline \multirow{2}{*}{ Çocuğunuz Var mı? } & Evet & 433 & 98,4 \\
\hline & Hayır & 7 & 1,6 \\
\hline
\end{tabular}




\begin{tabular}{|c|c|c|c|}
\hline \multirow{4}{*}{ Çocuk Sayısı } & 1 & 149 & 33,9 \\
\hline & 2 & 210 & 47,7 \\
\hline & 3 & 77 & 17,5 \\
\hline & 4 ve daha fazla & 4 & 0,9 \\
\hline \multirow[b]{2}{*}{ Kreşe Giden Çocuğunuz Var Mı? } & Evet & 433 & 98,4 \\
\hline & Hayır & 7 & 1,6 \\
\hline \multirow{3}{*}{ Kreşe Giden Çocuk Sayısı } & 1 & 356 & 80,9 \\
\hline & 2 & 78 & 17,7 \\
\hline & 3 ve daha fazla & 6 & 1,4 \\
\hline \multirow{5}{*}{ Çocuğun Gittiği Kreşin Tercih Nedenini } & Eve Yakın & 17 & 3,9 \\
\hline & Popüler & 7 & 1,6 \\
\hline & Arkadaşlarımın Tavsiyesi & 65 & 14,8 \\
\hline & Güvenilir & 192 & 43,6 \\
\hline & Uygun Fiyatlı & 159 & 36,1 \\
\hline \multirow{2}{*}{$\begin{array}{l}\text { Çocuğunuzun Gittiği Kreşin Eğitim } \\
\text { Süresi }\end{array}$} & Tam Gün & 171 & 38,9 \\
\hline & Yarım Gün & 269 & 61,1 \\
\hline \multirow{4}{*}{ Kreşe Ödediğiniz Ücret Miktarı Nedir? } & $400-600 \mathrm{TL}$ & 147 & 33,4 \\
\hline & $600-800 \mathrm{TL}$ & 146 & 33,2 \\
\hline & $800-1000 \mathrm{TL}$ & 130 & 29,5 \\
\hline & 1000 TL ve daha fazla & 17 & 3,9 \\
\hline
\end{tabular}

Tablo 3 incelendiğinde;

Çalışmaya katılanların \%67'si kadındır. Bu durum, çocuklarını kreşe bırakma ya da kreşten alma işini daha çok kadınların yaptıkları biçiminde yorumlanabilir. Çalışmaya katılan 440 kişinin yaş dağılımına bakıldığında, en çok katılanların yaş grubunun \%57 ile ile 35-44 yaş grubu olduğu görülmektedir. Çalışmaya katılanların eğitim durumu bakımından incelendiğinde, \% 69'unun üniversite mezunu olduğu, \%26'sının lise mezunu olduğu görülmektedir. Bu durum, üniversite mezunu kişilerin çocuklarını kreşe gönderme eğilimlerinin daha yüksek olduğunu göstermektedir. Aylık gelir bakımından katılımcıların \%36’sının aylık gelirinin 2000-3000 TL olduğu gözlemlenmiştir. Aylık toplam geliri yüksek olan kişilerin çocuklarının daha çok özel kreşlere gittiği, aylık toplam geliri daha az olan kişilerin ise genellikle devlet kreşlerini tercih ettiği de görülmüştür. Çalışmaya katılanların \%98'inin çocuğu olduğu görülmektedir. Çocuk sayısı bakımından değerlendirme yapıldığında ise, katılımcıların \%48'inin 2 çocuğu olduğu görülmektedir. Çalışmaya katılanlarının \%81'inin yalnızca bir çocuğunun kreşe gittiği ve \%18'inin de iki çocuğunun kreşe gittiği belirlenmiştir. 
Çalışmaya katılanların çocuğunun gittiği kreşi tercih etme nedenleri incelendiğinde, \%44'ünün kreşi güvenilir, \%36'sının ise kreşin ücretini uygun bulmasından dolayı tercih ettiği görülmektedir. Bu durumun, aylık gelir ve ailelerin eğitim düzeyleri ile de ilişkili olduğu anlaşılmıştır. Katılımcıların 440 katılımcıdan \%61'inin çocuklarının kreşlerden yarım gün eğitim almasını tercih ettikleri görülmektedir. Bu durum, anne ya da babaların çalışma saatleri ile de bağlantılıdır. Bir diğer durum ise, ailelerin maddi durumları çok iyi olmasa da çocuklarını yarım gün eğitim alabilecekleri bir kreşe göndermelidir. Öte yandan \%39'unun da çocuğunu tam gün eğitim alabileceği bir kreşe gönderdiği görülmektedir. Kreş için ödenen ücretler bakımından incelendiğinde, çalışmaya katılanların \%33'ünün kreşe 400-600 TL arasında bir ücret ödediği gözlemlenmektedir. \%33'ünün 600-800 TL ve \%30'ununda 800-1000 TL arasında bir ücret ödediği gözlemlenmektedir. Bu ücretler, kreşlerin tam gün ya da yarım gün hizmet vermesi ve kreşlerin özel ya da devlet kurumu olması ile de yakından ilgilidir.

\subsection{Faktör Analizi Sonuçları}

Ailelerin kreş tercihi ve kreşlerden beklentilerini etkileyecek faktörlerin hangileri olduğunu belirleyebilmek için 23 maddelik ölçek uygulanmış ve faktör analizi ile incelenmiştir. Faktör döndürme tekniği olarak Varimax döndürme tekniği kullanılmıştır.

Verilerin Faktör analizinin uygunluğu araştırılırken daha sonra Kaiser-Meyer-Olkin (KMO) Örneklem Yeterliliği Ölçütü kullanılır. KMO ölçütü, gözlenen korelasyon katsayılarının büyüklüğü ile kısmi korelasyon katsayılarının büyüklüğünü karşılaştırır. KMO ölçütü ayrıca, değişkenler arasındaki korelasyonları ve faktör analizinin uygunluğunu ölçmektedir. KMO oranının $(0,5)^{\prime}$ in üzerinde olması gerekmektedir. Bu oran, ne kadar yüksek olursa veri setinin faktör analizi uygulamak için o kadar uygun olduğu ifade edilebilir (Tatlıdil, 2002). 
KMO değerleri ve yorumları aşağıdaki gibidir:

Tablo 4. KMO Uygunluk Testi İçin Önerilen Kriterler

\begin{tabular}{cl}
\hline \hline KMO değerleri & Yorum \\
\hline 0,90 & Mükemmel \\
0,80 & Çok İyi \\
0,70 & İyi \\
0,60 & Orta \\
0,50 & Zayıf \\
0,50 'nin altı & Kabul Edilemez \\
\hline
\end{tabular}

Kaynak: (Yeşildağ, 2013)

Ölçekte yer alan tutum sorularının güvenirlik analizi için Cronbach $\alpha$ değeri kullanımaktadır. Cronbach $\alpha$ değeri 0.00-0.40 arasında ise, ölçeğin güvenilir olmadığı, 0.41-0.60 arasında ise, ölçeğin düşük güvenilir olduğu, 0.61-0.80 arasında ise, ölçeğin orta düzeyli güvenilir olduğu, 0.81-1.00 arasında ise, ölçeğin yüksek güvenilir olduğu ifade edilmektedir (Yaşar, 2014). Çalışmadan elde edilen KMO değeri 0.849 olarak hesaplanmıştır. Bu değer, örneklemin yeterliliğinin iyi olduğunu ifade etmektedir.

Verilerin Faktör analizinin uygunluğu araştırılırken önce korelasyon matrisi toplu olarak sınamak üzere Bartlett küresellik testi (Bartlett test of Sphericity) kullanılmaktadır. Bu test korelasyon matrisinin birim bir matris olup olmadığını test etmektedir. Korelasyon matrisinde yer alan değişkenlerin en azından bir kısmı arasında yüksek dereceli ilişkiler olma olasılığı araştırılır. Analize devam edebilmek için "Korelasyon matrisi birim matristir $(R=I)$ şeklinde tanımlanan" sıfır hipotezinin reddedilmesi gerekir. Bartlett testi sonucunda, sıfır hipotezi reddedilirse, değişkenler arasında yüksek ilişkiler olduğu ifade edilebilir. Başka bir ifadeyle faktör analizi uygulamak için veri setinin uygun olduğu söylenebilir. Çalışmada, Bartlett Küresellik testi sonucuna göre, Ki-Kare istatistiği 5523,26 olarak hesaplanmıştır ve sıfır hipotezi reddedilmiştir $(p<0.01)$. Bu sonuca göre, verilerin faktör analizine uygun olduğu belirlenmiştir. Faktör sayısını belirlerken özdeğeri 1'den büyük olan faktörler dikkate alınmıştır ve 5 faktör ortaya çıkmıştır (özdeğerleri sırasıyla, 6.457, $3.354,2.511,1.280,1.169)$. Faktörlerin varyans açıklama oranları sırasıyla, $\% 15,487, \%$ $13.159, \% 12.922, \% 10.72$ ve \% 9.258 olarak belirlenmiştir. Bu sonuca göre beş faktörün varyans açıklama oranı $\% 61.55^{\prime}$ tir.

Faktör analizinde, orijinal faktör yüklerinden bilgi elde etmek zor olabilir. Bundan dolayı, faktör yapısını daha basit hale getirmek üzere faktörler belirli bir açı ile döndürmek daha uygun olmaktadır. Faktör döndürmesi (rotasyonunu), faktör yüklerinin dik (ortogonal) hale getirilmesi için eksenlerin en uygun bir açı ile döndürülmesi ve böylelikle dikliğin 


\section{Fatih ÇEMREK | Özer ÖZAYDIN}

(ortogonalliğin) sağlanmasıdır. Yaygın olarak yararlanılan faktör döndürme teknikleri Varimax, Quartimax, Equimax, Orthomax, Oblique, Promax rotasyon gibi isimlerle anılmaktadır. Bu teknikler içinde en sık tercih edilen döndürme tekniği Varimax teknğidir (Esen, 2005). Varimax döndürme tekniğine göre elde edilen sonuçlar Tablo 5'te verilmiştir.

\section{Tablo 5. Faktör Analizi Sonuçları}

\begin{tabular}{|c|c|c|c|}
\hline Soru & & & \\
\hline Faktör 1 (Kreşte Verilen Eğitim) & $\begin{array}{l}\text { Varyans } \\
\text { açıklama } \\
\text { Oranı (\%) }\end{array}$ & $\begin{array}{l}\text { Faktör } \\
\text { ağırlığı }\end{array}$ & $\begin{array}{c}\text { Cronbach } \\
\text { Alfa }\end{array}$ \\
\hline $\begin{array}{l}\text { 36. Soru: Kreşte yaş grubuna göre çocuklara müzik } \\
\text { eğitiminin verilmesi önemlidir. }\end{array}$ & \multirow{4}{*}{15,487} & 0,891 & \multirow{4}{*}{0,753} \\
\hline $\begin{array}{l}\text { 35.Soru: Kreşte yaş grubuna göre çocuklara tiyat- } \\
\text { ro/drama eğitiminin verilmesi önemlidir. }\end{array}$ & & 0,887 & \\
\hline $\begin{array}{l}\text { 38. Soru: Kreşte yaş grubuna göre çocuklara re- } \\
\text { sim/sanat eğitiminin verilmesi önemlidir. }\end{array}$ & & 0,883 & \\
\hline $\begin{array}{l}\text { 37.Soru: Kreşte yaş grubuna göre çocuklara jimnas- } \\
\text { tik eğitiminin verilmesi önemlidir. }\end{array}$ & & 0,829 & \\
\hline Faktör 2 (Çalışan Davranışı ve Hizmetler) & $\begin{array}{l}\text { Varyans } \\
\text { açıklama } \\
\text { Oranı (\%) }\end{array}$ & $\begin{array}{l}\text { Faktör } \\
\text { ağırlığı }\end{array}$ & $\begin{array}{c}\text { Cronbach } \\
\text { Alfa }\end{array}$ \\
\hline $\begin{array}{l}\text { 32.Soru Öğretmenin çocuklara olan davranışları kreş } \\
\text { tercihimde etkilidir. }\end{array}$ & \multirow{7}{*}{13.159} & 0,768 & \multirow{7}{*}{0,775} \\
\hline $\begin{array}{l}\text { 31.soru Öğretmenin iletişimi, kreş tercihimde etkili- } \\
\text { dir. }\end{array}$ & & 0,665 & \\
\hline $\begin{array}{l}\text { 33.Soru: Kreş yönetiminin bilgilendirme sağlaması } \\
\text { kreş tercihimde önemlidir. }\end{array}$ & & 0,640 & \\
\hline $\begin{array}{l}\text { 15.Soru: Kreşin çocuğun çevresi ile iletişimini güç- } \\
\text { lendirecek aktiviteleri düzenlemesi oldukça önemli- } \\
\text { dir. }\end{array}$ & & 0,620 & \\
\hline $\begin{array}{l}\text { 20.Soru: Kreş bahçesi içerisinde park, aktivite alan- } \\
\text { ları vb. alanların olması kreş tercihim açısından } \\
\text { önemlidir }\end{array}$ & & 0,547 & \\
\hline $\begin{array}{l}\text { 30.Soru: Kreş binası herhangi bir ilkokul bina ve } \\
\text { bahçesinden bağımsız olmalıdır. }\end{array}$ & & 0,480 & \\
\hline $\begin{array}{l}\text { 14.Soru: Kreş çalışanlarının(yardımcı öğretmenlerin) } \\
\text { çocuklara olan davranışı kreş tercihimde önemlidir }\end{array}$ & & 0,417 & \\
\hline Faktör 3 (Kreşin Konumu ve Ücreti) & $\begin{array}{l}\text { Varyans } \\
\text { açılama }\end{array}$ & $\begin{array}{l}\text { Faktör } \\
\text { ağırlığı }\end{array}$ & $\begin{array}{l}\text { Cronbach } \\
\text { Alfa }\end{array}$ \\
\hline
\end{tabular}




\begin{tabular}{|c|c|c|c|}
\hline & Oranı (\%) & & \\
\hline $\begin{array}{l}\text { 21.Soru: Kreşin evime yakın olması, bu kreşi tercih } \\
\text { etmemde oldukça etkili bir sebeptir. }\end{array}$ & \multirow[b]{3}{*}{12.922} & 0,858 & \multirow[b]{3}{*}{0,845} \\
\hline $\begin{array}{l}\text { 22.Soru: Kreşin uygun bir ücrete sahip olması benim } \\
\text { için önemli bir tercih sebebidir. }\end{array}$ & & 0,835 & \\
\hline $\begin{array}{l}\text { 28.Soru: Ailede bulunan çocuk sayısının, kreş tercihi } \\
\text { üzerinde etkisi vardır. }\end{array}$ & & 0,814 & \\
\hline Faktör 4 (Güvenlik- Sağlık Hizmetleri) & $\begin{array}{l}\text { Varyans } \\
\text { açıklama } \\
\text { Oranı }(\%)\end{array}$ & $\begin{array}{l}\text { Faktör } \\
\text { ağırlığı }\end{array}$ & $\begin{array}{c}\text { Cronbach } \\
\text { Alfa }\end{array}$ \\
\hline $\begin{array}{l}\text { 27.Soru: Kreşlerde çocukların güvenlikleri açısından } \\
\text { güvenlik hizmetlerinin verilmesi oldukça önemlidir. }\end{array}$ & \multirow{4}{*}{10.720} & 0,818 & \multirow{4}{*}{0,871} \\
\hline $\begin{array}{l}\text { 26.Soru: Çocukların düzenli ve sağlıklı beslenebilme- } \\
\text { leri için kreşlerde çocuklara uygun olarak hazırlanan } \\
\text { yemek hizmeti de verilmelidir. }\end{array}$ & & 0,788 & \\
\hline $\begin{array}{l}\text { 18.Soru: Kreş içerisinde sağlık hizmetlerinin de bu- } \\
\text { lunması gerekir. }\end{array}$ & & 0,776 & \\
\hline $\begin{array}{l}\text { 19.Soru: Kreş donanımının(tuvalet, lavabo vb.) ço- } \\
\text { cuklar için uygun şekilde olmalıdır. }\end{array}$ & & 0,553 & \\
\hline
\end{tabular}

Tablo 5. Faktör Analizi Sonuçları (Devam)

\begin{tabular}{|c|c|c|c|}
\hline Faktör 5 (Aktivite) & $\begin{array}{l}\text { Varyans } \\
\text { açılama } \\
\text { Oranı (\%) }\end{array}$ & $\begin{array}{l}\text { Faktör } \\
\text { ağırlığı }\end{array}$ & Cronbach Alfa \\
\hline $\begin{array}{l}\text { 25.Soru: Kreşlerin kültürel gezileri düzenlemesi } \\
\text { gerekir. }\end{array}$ & \multirow{5}{*}{9.258} & 0,645 & \multirow{6}{*}{0,825} \\
\hline $\begin{array}{l}\text { 24.Soru: Kreşlerde yabancı dil eğitimlerinin } \\
\text { verilmesi gerekir. }\end{array}$ & & 0,612 & \\
\hline $\begin{array}{l}\text { 17.Soru: Kreş sınıfları hazırlanırken, çocukların } \\
\text { aynı yaşta olması benim için önemlidir. }\end{array}$ & & 0,551 & \\
\hline $\begin{array}{l}\text { 23.Soru: Kreşin ulaşım için hizmet( servis sağla- } \\
\text { ması) vermesi oldukça önemlidir. }\end{array}$ & & 0,506 & \\
\hline $\begin{array}{l}\text { 16.Soru: Öğretmenin çocuk gelişimi alanında } \\
\text { üniversite mezunu olması kreş tercihimde son } \\
\text { derece etkilidir. }\end{array}$ & & 0,465 & \\
\hline KMO:0.849, Bartlett Küresellik Testi: 5523,26 (p< & .01), Cronk & ch Alfa:0. & \\
\hline
\end{tabular}


Fatih ÇEMREK | Özer ÖZAYDIN

almıştır. Aynı zamanda 35., 38. ve 34. Sorular da birinci faktör altında yüksek ağırlığa sahip olan diğer sorulardır. İkinci faktör (Çalışan Davranışı ve Hizmetler) altında 32. Soru en büyük ağırlığı almıştır. 31., 33., 15. ,20.,30. Ve 14.sorular da ikinci faktör altında yüksek ağırlığa sahip olan sorulardır. Üçüncü faktör ( Kreşin Konumu ve Ücreti ) altında 21. Soru en büyük ağırlığı alan sorudur. 22. ve 28. Sorular yine üçüncü faktör altında yüksek ağırlığı alan sorular olmaktadır. Dördüncü faktör altında (Güvenlik- Sağlık Hizmetleri ) 27. Soru en büyük ağırlığı alan sorudur. 26., 18. ve 19. Sorular da yine dördündü faktör altında yüksek ağırlığa sahip olan sorular olmuştur. Beşinci faktör (Aktivite) altında 25. Soru en büyük ağırlığı alan sorudur. 24., 17. 23. Ve 16. sorular da beşinci faktör altında yüksek ağırlığa sahip olan sorulardır.

Ayrıca, Tablo 4'te her faktörde yer alan tutuma ilişkin maddelerin faktör yükleri ile her bir faktöre ilişkin Cronbach Alpha güvenirlik katsayılarına yer verilmiştir. Tablo 4 incelendiğinde, faktör yüklerinin 0.417 ile 0.891 arasında değişmekte olduğu görülmektedir. Her bir faktöre ilişkin faktör yükleri birbirinden ayrı olarak incelendiğinde, 1. Faktörün, faktör yükleri 0.829 ile 0.891 , 2. Faktörün, faktör yükleri 0.417 ile $0.768 ; 3$. Faktörün, faktör yükleri 0.814 ile 0.858 ; 4.Faktörün, faktör yükleri 0.553 ile,0.818, ve 5 . Faktörün, faktör yükleri, 0.5465 ile 0.645 , arasındadır.

Her bir faktöre ilişkin Cronbach Alpha güvenirlik katsayılarının 0.75 ile 0.871 arasında değiştiği görülmektedir. Bu durum, her bir faktörün güvenilir olduğunu ifade etmektedir.

Faktörlerde yer alan sorular incelendiğinde; 1. Faktörde en çok ağırlığı olan soru 36. Soru (Kreşte yaş grubuna göre çocuklara müzik eğitiminin verilmesi önemlidir). 2. Faktörde en çok ağırlığı olan soru 32. Soru (Soru Öğretmenin çocuklara olan davranışları kreş tercihimde etkilidir). 3. Faktörde en çok ağırlığı olan soru 21. Soru (Kreşin evime yakın olması, bu kreşi tercih etmemde oldukça etkili bir sebeptir). 4. Faktörde en çok ağırlığı olan soru 27. Soru (Kreşlerde çocukların güvenlikleri açısından güvenlik hizmetlerinin verilmesi oldukça önemlidir). 5. Faktörde en çok ağırlığı olan soru 25. Soru ( Kreşlerin kültürel gezileri düzenlemesi gerekir).

\section{Sonuç, Tartışma ve Öneriler}

Bu çalışmada Eskişehir'de yaşayan ailelerin çocuklarının eğitim aldıkları kreş tercihleri ve kreşlerden beklentileri belirlenmeye çalışılmıştır. Araştırma evrenini 2015-2016 öğretim yılında Eskişehir'de kreşe giden çocukların ailelerinin tamamı oluşturmaktadır. Araştırma örneklemini ise, 2015-2016 öğretim yılında Eskişehir'de kreşe giden çocukların aileleri arasından rassal olarak seçilen 440 ailenin tamamı oluşturmaktadır. 
Araştırmada kullanılan ankette yer alan sorular iki bölümden oluşmuştur. Birinci bölümde ailelerin sosyo-ekonomik özelliklerine ilişkin sorular yer almaktadır. İkinci bölümde ise, ailelerin kreş tercihi ve kreşlerden beklentilerine ilişkin olarak tutum ve görüşlerin yer aldığı beşli Likert tipi 23 tutum sorusu yer almıştır. Bu soruların değerlendirilmesinde 5'li Likert tipi ölçek kullanılmıştır. Her bir soru için anketi cevaplayanlar 1:Kesinlikle Katılmıyorum, 2: Katılmıyorum, 3:Kararsızım, 4:Katılıyorum ve 5: Kesinlikle Katılıyorum şeklinde ifade edilen cevaplardan birisini işaretlemişlerdir.

Ankete verilen cevapların güvenirliğini belirlemek üzere hesaplanan Cronbach $\alpha$ güvenilirlik katsayısı değeri 0.854 olarak hesaplanmıştır ve anketin güvenirliği oldukça yüksek olduğu sonucu belirlenmiştir. Ayrıca, değişkenler arasında negatif korelasyonlu değişken olmadığı belirlenmiştir.

Faktör analizinde örneklem büyüklüğünün yeterliliğini test etmek üzere uygulanana Kaiser-Meyer- Olkin (KMO) testine göre KMO değeri 0.849 olarak hesaplanmıştır. Buradan örneklemin yeterliliğinin iyi olduğu ifade edilebilir. Verilerin Faktör analizine uygun olup olmadığını belirlemek için Bartlett Küresellik Testi yapılmıştır. Bartlett Küresellik testi sonucuna göre, hesaplanan ki-kare istatistiği değeri 5523,262'dır $(p<0.01)$ olup, veriler faktör analizine uygun olduğu belirlenmiştir. Uygulanan faktör analizi sonucunda özdeğeri 1'den büyük olan 5 faktör ortaya çıkmıştır (özdeğerleri sırasıyla, 6.457, 3.354, 2.511, $1.280,1.169$. Bu 5 faktörün varyans açıklama oranı \%66.01'tir. Birinci faktör "kreşte verilen eğitim", ikinci faktör "Çalışan Davranışı ve Hizmetler", üçüncü faktör "Kreşin Konumu ve Ücreti", dördüncü faktör "Güvenlik- Sağlık Hizmetleri",ve beşinci faktör "Aktivite" olarak adlandırılmıştır.

Anne-babaların çocuklarını okul öncesi eğitim kurumlarından biri olan kreşlerden beklentileri üzerinde anne-babaların eğitim düzeyi, gelir düzeyi gibi farklı sosyodemografik özelliklerinin farklılıklara neden olduğu belirlenmiştir.

Anne-babaların kreş tercihi yaparken göz önünde bulundurdukları faktörler de tespit edilmiştir.

Kreşte yaş grubuna göre çocuklara müzik, tiyatro/drama, resim/sanat ve jimnastik eğitimlerinin verilmesi, aileler için önemli bir beklentidir. Kreş tercihinde, kreş çalışanlarının çocuklara olan davranışı, öğretmenin iletişimi ve davranışları, kreş yönetiminin bilgilendirme sağlaması, kreşin çocuğun çevresi ile iletişimini güçlendirecek aktiviteleri düzenlemesi ve kreş içerisinde park, aktivite alanı vb. alanları olması ailelerin kreş tercihi açısından etkilidir.

Kreşin ailelerin evine yakın olması, uygun bir ücrete sahip olması ve ailenin sahip olduğu çocuk sayısı da aileler için önemli bir tercih sebebi olabilmektedir. Kreşlerde çocuk- 
Fatih ÇEMREK | Özer ÖZAYDIN

ların güvenlikleri açısından güvenlik hizmetinin verilmesi, çocuklar için özel olarak hazırlanan yemeklerin bulunması, kreş içerisinde sağlık hizmetlerinin bulunması ve kreş donanımının çocuklar için uygun bir şekilde hazırlanması ailelerin kreş tercihi sırasında göz önünde bulundurduğu önemli faktörlerdir.

Kreşlerin düzenlediği kültürel geziler, verilen yabancı dil eğitimleri, sınıflarda aynı yaş grubuna ait olan çocukların olması ve kreşin servis imkânı sunması da aileler için oldukça önemli olmaktadır.

Ailelerin kreş tercihlerinde etkili olan bu faktörler, aynı zamanda ailelerin kreşlerden olan beklentilerini de oluşturmaktadır. Okul öncesi eğitim kurumlarında, özellikle de donanım ve verilen eğitimler konusunda yapılacak olan olumlu gelişmeler, ailelerin beklentilerini karşılayabilecektir. Ayrıca, anne-babalara okul öncesi eğitim konusunda çok daha kapsamlı bilgilerin verilmesi gerekmektedir.

\section{Teşekkür}

Verilerin toplanmasındaki katkılarından dolayı Aysu AYKANAT’a teşekkür ederiz.

\section{Kaynaklar}

Arıkan, R. (2004). “Araştırma Teknikleri ve Rapor Hazırlama”, Asil Yayın, Ankara.

Argon, T. ve Akkaya, M., (2008). “Ebeveynlerin Okul Öncesi Eğitime Ve Okul Öncesi Eğitim Kurumlarına Yönelik Görüşleri”, Kastamonu Eğitim Dergisi, Ekim 2008, Cilt:16, No:2, 413-430.

Aslanargun, E. ve Tapan, F. (2012), "Okul Öncesi Eğitim ve Çocuklar Üzerindeki Etkileri”, Abant İzzet Baysal Üniversitesi Eğitim Fakültesi Dergisi, Cilt:11, Sayı: 2, s. 219,238

Baran M., Yıımaz, A., Yıldırım, M., (2007).“Okul Öncesi Eğitimin Önemi ve Okul Öncesi Eğitim Yapılarındaki Kullanıcı Gereksinimleri: Diyarbakır Huzurevleri Anaokulu Örneği", Dicle Üniversitesi Ziya Gökalp Eğitim Fakültesi Dergisi 8, 27-44.

Bozan, N., (2014), “Okul Öncesi Eğitimde Oyunun Öğretmen Görüşlerine Göre Değerlendirilmesi," Atatürk Üniversitesi Eğitim Bilimleri Enstitüsü IIlköğretim Ana Bilim Dalı Sınıf Öğretmenliği Bilim Dalı Yüksek Lisans Tezi, Erzurum. 
Durualp, E, Kaytez, N., Kadan, G. (2016). Okul öncesi dönemdeki çocukların annelerine verilen aile eğitiminin annelerin bilgi düzeyleri ile çocukların gelişimlerine olan etkisinin incelenmesi. Abant İzzet Baysal Üniversitesi Eğitim Fakültesi Dergisi, 16(4), 17061722.

Erkan, S. ve Kırca, A. (2010). Okul öncesi eğitimin ilköğretim birinci sınıf öğrencilerinin okula hazır bulunuşluklarına etkisinin incelenmesi. Hacettepe Üniversitesi Eğitim Fakültesi Dergisi, 38, 94-106.

Esen, E., (2005), “ Nükleer Bilimler ve Kimyadaki Deneysel Sonuçların Faktör Analizi Kullanılarak İncelenmesi”, Celal Bayar Üniversitesi Fen Bilimleri Enstitüsü Fizik Ana Bilim Dalı Yüksek Lisans Tezi.

Kanbak Ay, Güler, Yıldırım Bilal ve Kadıoğlu Ateş Hatice (2016), “Okul Öncesi Öğretmenlerinin Mesleki Yeterlilik Algılarının İncelenmesi (Başakşehir İlçesi Örneği) “Akademik Bakış Dergisi, Sayı: 55, Mayıs - Haziran 2016, 89-108.

Kargı, E (2011), “Niçin Okul Öncesi Eğitim”, Eğitime Bakış Dergisi, Nisan-Mayıs-Haziran 2011, Sayı:20, sf.5-8.

Kıldan, A.O., (2012), “Okul Öncesi Eğitimin Amacına İlişkin Öğretmen ve Veli Görüşleri”, Kastamonu Eğitim Dergisi, Cilt:20 No:1, 135-150

Kobak, C., (2009), “ Anaokulundaki Çocukların Beslenme Özelliklerinin Karşılaştırılması”, Türkiye Cumhuriyeti Marmara Üniversitesi Sağlık Bilimleri Enstitüsü Çocuk Sağlığı Ve Hastalıkları Hemşireliği Anabilim Dalı, Yayımlanmamış Yüksek Lisans Tezi, İstanbul

Mutlu, B., Ergişi, A., Bütün Ayhan, A., Aral, N., (2012), “Okul Öncesi Dönemde Montessori Eğitimi”, Ankara Sağlık Bilimleri Dergisi, Cilt:1, Sayı:3, 113-128

Oktay, A., (2002). “ Türkiye'de Okul Öncesi Eğitimin Dünü ve Bugünü”, Eğitim ve Bilim Dergisi,S.3-7,istanbul.

(http://egitimvebilim.ted.org.tr/index.php/EB/article/view/5743/1872)

Özen Altınkaynak, Ş. ve Yanıklar C., (2014), “Anne ve Babaların Okul Öncesi Eğitime Devam Eden Çocuklarının Gelişimine Yönelik Beklentileri”, Mehmet Akif Ersoy Üniversitesi Eğitim Fakültesi Dergisi, Haziran 2014, Sayı 30, 56 - 72 
Fatih ÇEMREK | Özer ÖZAYDIN

Pianta, R.C, Barnett, W. S., Burchinal, M. and Thornburg, K.R. (2010), "The Effects of Preschool Education: What We Know, How Public Policy Is or Is Not Aligned With the Evidence Base, and What We Need to Know" Psychological Science in the Public Interest, 10(2), 49-88.

Peterson, J., Bruce J., Patel N., Chamberlain L.J., (2018), “Parental Attitudes, Behaviors, and Barriers to School Readiness among Parents of Low-Income Latino Children", International Journal of Environmental Research and Public Health, Jan 24;15(2)

Polat, C., Çelmeli, Ö., (2015), “ Okulöncesi Eğitim Kurumu Seçiminde Tüketici Tercih Etkenleri”, Kastamonu Üniversitesi İktisadi ve İdari Bilimler Fakültesi Dergisi, Sayi:8.

Polat Yaman, R. ve Saçkes, M., (2017), “Anne-babalar okul öncesi eğitim kurumu yöneticilerinden ne bekliyor? Anne-baba ve yönetici beklentilerinin karşılaştırılması", Erken Çocukluk Çalışmaları Dergisi, Cilt: 1 Sayı: 1 Nisan 2017 s.94-103

Rentzou, K. (2012), “Exploring parental preferences: care or education: what do Greek parents aspire from day care centres?, "Child Care in Practice, Vol:18, 2012 - Issue 2,1906-1923.

Sevinç, M. (2006), “Okul Öncesi Eğitimi Alan Çocukların Annelerinin Okuldan Beklentileri”, Kazım Karabekir Eğitim Fakültesi Dergisi, Sayı:13, 218-225.

Şimşek, Z., İvrendi A., (2014), “Ebeveynlerin okul öncesi eğitim kurumlarından beklentileri. “ Hacettepe Üniversitesi Eğitim Fakültesi Dergisi, 29(2), s. 240-254.

Tatlıdil, H. (2002) "Uygulamalı Çok Değişkenli İstatistiksel Analiz", Hacettepe Üniversitesi İstatistik Bölümü, Ankara.

Topaç, N., Yaman Y., Ogurlu Ü., İlgar L., (2012), “Okul Öncesi Dönem Çocuğu Olan Ailelerin Okul Öncesi Eğitim Kurumu Seçerken Göz Önünde Bulundurdukları Ölçütlerin İncelenmesi", New Trends on Global Education Conference, 24-26 September 2012Girne, KKTC,

Tuğrul, B. ve Tokuç, H. ( 2007). Anne ve Babaların Okul Öncesi Eğitim Hakkındaki Görüş ve Beklentilerinin İncelenmesi, 1, Ulusal İlköğretim Kongresi, Hacettepe Üniversitesi, Ankara

Yaşar, M., (2014), “istatistiğe Yönelik Tutum Ölçeği: Geçerlilik ve Güvenirlik Çalışması”, Pamukkale Üniversitesi Eğitim Fakültesi Dergisi, Sayı 36 (Temmuz 2014/II), 59-75 
Yazıcıoğlu, Y. ve Erdoğan, S. (2004) "SPSS Uygulamalı Bilimsel Araştırma Yöntemleri" Ankara: Detay Yayıncılık.

Yeşildağ, E., (2013), "Türkiye'de Aracı Kuruluşların Gelişimi ve Yatıımcıların Aracı Kuruluş Seçimine Etki Eden Unsurlar: Bir Faktör Analizi Uygulaması", Adnan Menderes Üniversitesi Sosyal Bilimler Enstitüsü İşletme Anabilim Dalı.

Yoleri, S., ve Tanış, H.M., (2014), “ilkokul Birinci Sınıf Öğrencilerinin Okula Uyum Düzeylerini Etkileyen Değişkenlerin İncelenmesi", Karabük Üniversitesi Sosyal Bilimler Enstitüsü Dergisi, Cilt:4, Sayı:2, 130-141. 